\title{
Population connectivity of red drum in the northern Gulf of Mexico
}

\author{
Jay R. Rooker ${ }^{1, *}$, Gregory W. Stunz ${ }^{2}$, Scott A. Holt ${ }^{3}$, Thomas J. Minello ${ }^{4}$ \\ ${ }^{1}$ Department of Marine Biology, Texas A\&M University, 5007 Avenue U, Galveston, Texas 77551, USA \\ ${ }^{2}$ Harte Research Institute for Gulf of Mexico Studies and the Department of Life Sciences, Texas A\&M University-Corpus Christi, \\ 6300 Ocean Drive, Corpus Christi, Texas 78412, USA \\ ${ }^{3}$ Department of Marine Science, The University of Texas Marine Science Institute, 750 Channelview Drive, Port Aransas, \\ Texas 78373, USA \\ ${ }^{4}$ National Marine Fisheries Service, Galveston Laboratory, 4700 Avenue U, Galveston, Texas 77551, USA
}

\begin{abstract}
Stable carbon $\left(\delta^{13} \mathrm{C}\right)$ and oxygen $\left(\delta^{18} \mathrm{O}\right)$ isotope ratios in otoliths were used to assess the degree of connectivity between early life and adult habitats of red drum Sciaenops ocellatus in the northern Gulf of Mexico. Young-of-the-year (YOY) red drum were sampled over a 3 yr period from major estuaries along the Texas coast, and otolith $\delta^{13} \mathrm{C}$ and $\delta^{18} \mathrm{O}$ were quantified to determine whether chemical tags in otoliths were region specific. North to south gradients were pronounced for otolith $\delta^{13} \mathrm{C}$ and $\delta^{18} \mathrm{O}$, with values being higher (enriched in the heavier isotope) for YOY red drum from southern estuaries relative to those in the north. Four distinct regional groups of YOY red drum were identified using otolith $\delta^{13} \mathrm{C}$ and $\delta^{18} \mathrm{O}$ : North $(\mathrm{N})$, Sabine Lake and East Galveston Bay; NorthCentral (NC), Christmas Bay and Matagorda Bay; South-Central (SC), Aransas Bay and Redfish Bay; and South (S), Laguna Madre. Overall classification success to these regional nurseries was high for each year examined: 2001 (92\%), 2002 (82\%) and 2003 (90\%). Mixed-stock analysis performed with age-2+ red drum collected in 2003 matched to the 2001 YOY baseline indicated that most of the subadult and adult red drum sampled in the $\mathrm{S}$ and $\mathrm{SC}$ regions were produced from the same areas (82 to $91 \%)$, with limited exchange between these regions. Mixing was more pronounced in the northern regions $(\mathrm{N}, \mathrm{NC}$ ), with a large percentage (35 to $42 \%$ ) of individuals originating from the adjacent region to the south. Overall, the majority of sub-adult and adult red drum was collected within or near the same region occupied during the YOY period, suggestive of natal homing, retention within specific estuarine corridors, or lower survivability of recruits migrating from distant regions.
\end{abstract}

KEY WORDS: Otolith chemistry $\cdot$ Site fidelity $\cdot$ Natal homing $\cdot$ Residency $\cdot$ Stable isotopes $\cdot$ Stock identification · Estuarine contribution · Nursery origin $\cdot$ Red drum

Resale or republication not permitted without written consent of the publisher

\section{INTRODUCTION}

Many fishes use estuaries to complete their life cycles and often spend months to years in these environments before migrating to coastal waters (Able et al. 2007). The degree of connectivity between estuarine and coastal environments is increasingly implicated as a key factor regulating population dynamics (Able 2005, Gillanders 2005). In response, a variety of approaches have been employed in recent years to assess movement and connectivity within and across estuaries, including numerical transport models (Brown et al. 2004), tagging (Bottom et al. 2005), genetics (Bradbury et al. 2008) and otolith chemistry (Gillanders 2002, Rooker et al. 2004, Fodrie \& Herzka 2008). Despite the fact that information on movement and mixing is considered fundamental to managing estuarine-associated fishes (Levin \& Stunz 2005) and assessing estuarine nursery value (Beck et al. 2001), the degree of connectivity at local and regional scales is still poorly understood for many taxa (Secor \& Rooker 2005). 
Chemical markers in otoliths are often used to assess population connectivity because otolith material deposited during the first year of life serves as a nursery tag (Campana 1999). To date, both trace elements and stable isotopes have been used to successfully discriminate fishes from different estuarine, coastal and marine environments, and to determine whether recruits originated from local or distant nurseries (Thorrold et al. 2001, Elsdon et al. 2008, Rooker et al. 2008a). Although trace elements serve as viable chemical tags for evaluating connectivity between estuarine and coastal habitats, strong interannual variability in these chemical signatures is relatively common, often requiring age-class matching of baseline samples to those of unknown origin (Thorrold et al. 1997, Gillanders 2005). Recent studies using carbon $\left(\delta^{13} \mathrm{C}\right)$ and oxygen $\left(\delta^{18} \mathrm{O}\right)$ stable isotope ratios indicate a high degree of accuracy in classifying individuals to nurseries coupled with lower interannual variability (Kerr et al. 2007, Rooker et al. 2008b), suggesting stable isotope ratios may serve as useful nursery tags.

Red drum Sciaenops ocellatus support a valuable sport fishery in estuarine and coastal waters of the Gulf of Mexico, and an improved understanding of regional production and connectivity of Gulf populations of red drum and other estuarine-dependent species is needed to develop efficacious conservation strategies. It is well established that red drum move between early life (estuarine) and adult (estuarine/coastal) habitats; however, the degree of mixing by red drum produced in different nurseries and the level of site fidelity and/or natal homing displayed by individuals remains unresolved. The purpose of the present study was to characterize otolith $\delta^{13} \mathrm{C}$ and $\delta^{18} \mathrm{O}$ in red drum from regional nurseries and then use region-specific tags to predict the nursery origin of sub-adults and adults, and to assess the degree of mixing and population connectivity.

\section{MATERIALS AND METHODS}

Young-of-the-year (YOY) red drum (mean \pm SD total length $=27.7 \pm 7.1 \mathrm{~cm})$ were collected by hookand-line over a 3 yr period (2001-2003) from bays and estuaries along the Texas Gulf Coast (from north to south): Sabine Lake, East Bay, Galveston Bay, Christmas Bay, Matagorda Bay, Aransas Bay, Redfish Bay and Upper/Lower Laguna Madre (Fig. 1). Sub-adult and adult red drum (age-at-maturity ca. age-1 to age- 2 for males and age-3 to age-4 for females, Murphy \& Taylor 1990) were collected by hook-and-line in 2003 near tidal passes or in coastal environments from several regions during the fall spawning event (September to November): Galveston Bay, Matagorda Bay, Corpus Christi Bay (includes Aransas Bay and Redfish

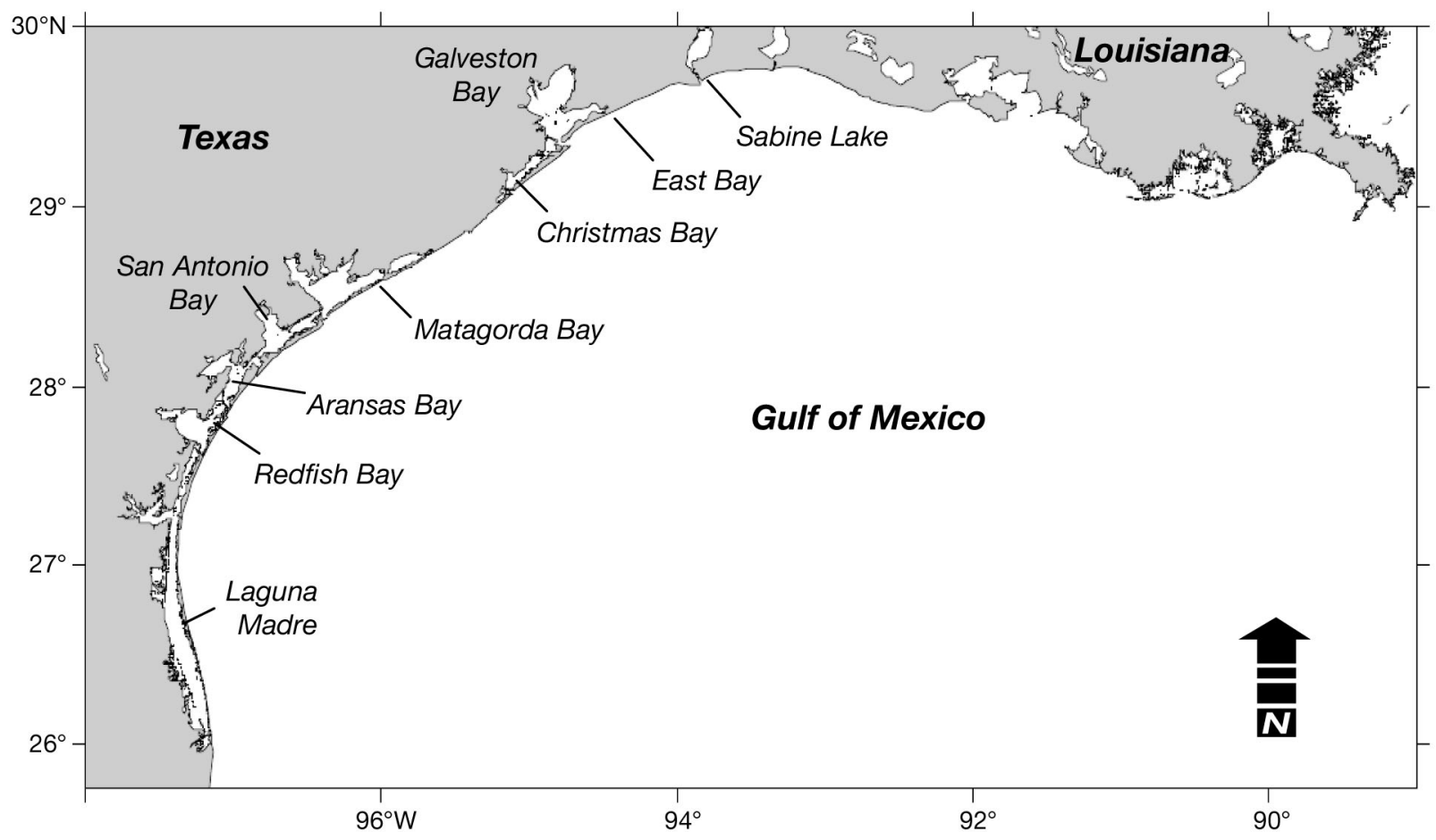

Fig. 1. Study area in the northern Gulf of Mexico with major bay systems shown 
Table 1. Sciaenops ocellatus. Collection information for young-of-the-year (YOY) and sub-adult/adult red drum collected from 4 regions in the northern Gulf of Mexico: North $(\mathrm{N})$, North Central (NC), South Central (SC) and South (S). n: sample size. Location codes: Aransas Bay (AB), Christmas Bay (CB), East Bay (EB), Galveston Bay (GB), Lower Laguna Madre (LL), Matagorda Bay (MB), Redfish Bay (RB), San Antonio Bay (SA), Sabine Lake (SL) and Upper Laguna Madre (UL)

\begin{tabular}{|ccccc|}
\hline \multirow{2}{*}{ Year } & Region & Collection site (n) & \multicolumn{2}{c|}{ Total length (cm) } \\
& & & Mean & Range \\
\hline YOY & & & & \\
2001 & N & EB (12), GB (9), SL (13) & 29.7 & $24.9-35.2$ \\
& NC & CB (14), MB (12) & 23.9 & $19.1-29.5$ \\
& SC & AB (16), RB (9) & 21.3 & $16.0-28.7$ \\
& S & LL (11), UL (10) & 22.2 & $17.4-34.2$ \\
2002 & N & EB (5), SL (11) & 28.5 & $15.0-33.5$ \\
& NC & CB (12), MB (11) & 25.8 & $18.3-33.0$ \\
& SC & AB (12), RB (10) & 22.3 & $17.5-32.0$ \\
& S & LL (7), UL (13) & 22.8 & $16.0-30.5$ \\
2003 & N & EB (8), SL (10) & 30.8 & $27.0-33.5$ \\
& NC & & & \\
& SC & AB (5) & 25.4 & $22.5-31.9$ \\
Sub-adult/adult & LL (6), UL (13) & 25.3 & $20.0-30.7$ \\
2003 & N & GB (21), SL (11) & 74.9 & $62.6-106.0$ \\
& NC & MB (25) & 66.3 & $62.2-77.0$ \\
& SC & AB (32), RB (12), SA (9) & 77.3 & $63.0-100.7$ \\
& S & LL (23), UL (18) & 68.3 & $62.0-80.0$ \\
\hline
\end{tabular}

Bay) and Laguna Madre (Table 1). In addition, a smaller number of sub-adults or adults were sampled from these regions in May to August. For the purpose of the present study, age-2+ red drum is used to designate individuals collected in the summer or fall of the year approaching or slightly past their third birthday or the transition from age-2 to age-3 (lengths converted to age based on Murphy \& Taylor 1990), suggesting that our sample of age-2+ or older red drum was likely comprised predominantly of young adults.

Sagittal otoliths of YOY and adult red drum were extracted, cleaned and rinsed with deionized water $\left(\mathrm{DIH}_{2} \mathrm{O}\right)$. Whole otoliths of YOY red drum were powdered with an acid-washed mortar and pestle. For age$2+$ and older red drum, sagittal otoliths were embedded in Struers epoxy resin and sectioned using a low-speed Buehler IsoMet® saw to obtain a $2.0 \mathrm{~mm}$ transverse section containing the core. Otolith sections were attached to a sample plate on a New Wave MicroMill System (New Ware Research), and the portion of the otolith corresponding to the YOY period was milled and removed. The drill path for the YOY section was a standard template with measurements derived from a series of sectioned otoliths from red drum 20 to $22 \mathrm{~cm}$ in total length (mean age ca. 7 to $8 \mathrm{mo}$; Fig. 2). Approximately 30 passes were made at a depth of $60 \mu \mathrm{m}$ to isolate core material from the otolith. Surface

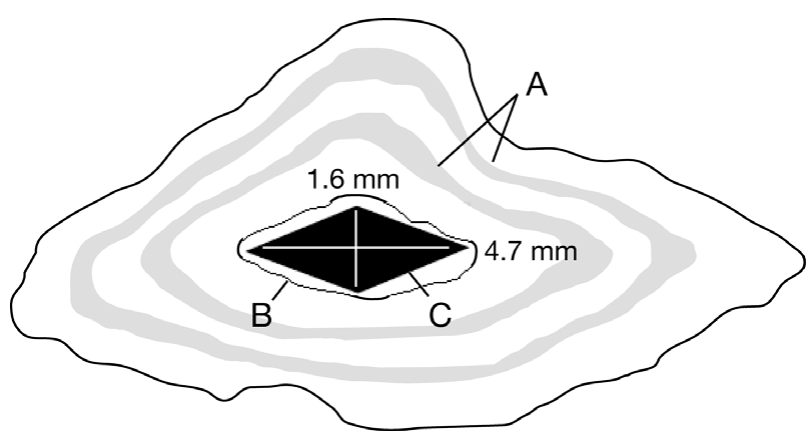

Fig. 2. Sciaenops ocellatus. Diagram of transverse section of otolith showing (A) annuli, (B) cross-section of sagittal otolith of young-of-the-year red drum, and (C) core material removed from transverse section ( $2.0 \mathrm{~mm}$ thick) of adult. Resulting prism was $1.6 \mathrm{~mm}$ (height) $\times 4.7 \mathrm{~mm}$ (width)

profiling was performed on each otolith to correct for bevelling in the section. Cored material was displaced as an intact diamond-shaped prism from the section and rinsed with $\mathrm{DIH}_{2} \mathrm{O}$ before being powdered. Otolith $\delta^{13} \mathrm{C}$ and $\delta^{18} \mathrm{O}$ were measured on a stable isotope mass spectrometer maintained at the Isotope Geochemistry Laboratory, Department of Geology, University of Maryland, USA. Stable $\delta^{13} \mathrm{C}$ and $\delta^{18} \mathrm{O}$ isotope ratios reported here are based on isotopic ratios of ${ }^{13 / 12} \mathrm{C}$ and ${ }^{18 / 16} \mathrm{O}$ relative to an in-house standard calibrated to Pee Dee Belemnite.

Hierarchical cluster analysis based on otolith $\delta^{13} \mathrm{C}$ and $\delta^{18} \mathrm{O}$ of YOY red drum was used to partition bays and estuaries sampled into regional groups for statistical testing. Cluster analysis was performed using normalized Euclidean distance (root mean square distances) and average linkage. A 2-way mixed model ANOVA was performed with Year (random factor) nested within Region (fixed factor) to examine regional and interannual variability in otolith $\delta^{13} \mathrm{C}$ and $\delta^{18} \mathrm{O}$ of YOY red drum. One-way ANOVAs were also used to examine the effect of Region (fixed factor) on otolith $\delta^{13} \mathrm{C}$ and $\delta^{18} \mathrm{O}$ separately for each of the 3 years. Quadratic discriminant function analysis (QDFA) was used to classify YOY red drum because the variancecovariance matrix of predictor variables was dissimilar among samples from different regions (Rooker et al. 2008b). Otolith weights and fish lengths were slightly different among regions and years, but no size effect was detected for otolith $\delta^{13} \mathrm{C}$ and $\delta^{18} \mathrm{O}$. Consequently, we did not adjust for differences in otolith weight among YOY red drum in our baseline sample.

A maximum likelihood based mixed-stock analysis program HISEA developed by Millar (1990) was used to predict the nursery origin of sub-adult and adult red drum. The baseline data set used for mixed-stock analysis was comprised of whole otolith $\delta^{13} \mathrm{C}$ and $\delta^{18} \mathrm{O}$ 
values of YOY red drum, while estimates of origin for sub-adults and adults collected in 2003 (age-2+) were based on isotopic values of otolith cores milled from transverse sections (corresponding to the YOY period). Age-2+ red drum collected in 2003 were matched with the 2001 baseline of YOY red drum, and direct matching was possible for over $60 \%$ of our unknown samples (Fig. 3). For the remaining age-3+ or older red drum with YOY periods before 2001, the 2001 baseline was used for predictions of nursery origin. Standard deviations around estimated proportions for sub-adult and adult red drum of unknown origin were generated in HISEA by bootstrapping with 500 resamplings of the baseline. Our sampling of nurseries along the coast of Texas was comprehensive; however, baseline (YOY) and unknown (sub-adults and adults) samples were plotted in ordination space to further evaluate whether all potential source populations were sampled. Only $2.6 \%$ of our unknown sample $(\mathrm{n}=4)$ fell outside the $95 \%$ confidence ellipse of the baseline, suggesting that our baseline likely included all possible nurseries. Nevertheless, these 4 individuals were removed from the data set to assure that contribution estimates were not biased by nurseries not sampled (Hamer et al. 2005, Chittaro et al. 2009).

Ontogenetic variability in otolith $\delta^{13} \mathrm{C}$ and $\delta^{18} \mathrm{O}$ can occur during the first year of life in marine fishes (Schloesser 2009), and thus the otolith isotopic composition of YOY red drum may not be homogenous throughout the carbonate matrix. In response, paired comparisons were run on whole otoliths and milled otolith cores from YOY red drum to determine whether the 2 approaches provided comparable measurements of otolith isotopic composition. No differences were

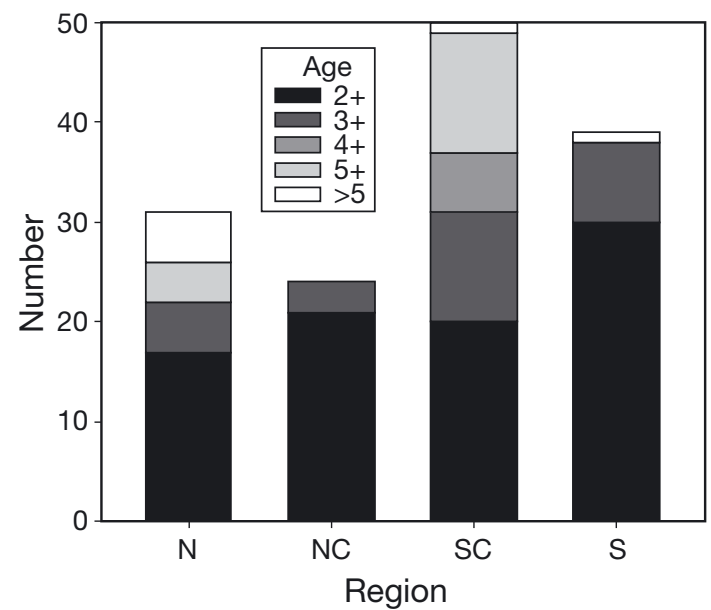

Fig. 3. Sciaenops ocellatus. Age-frequency distribution of sub-adult and adult red drum collected in 2003 from 4 sampling regions. Lengths converted to age based on Murphy \& Taylor (1990). Age-2+ red drum represent individuals matched to 2001 baseline sample detected in paired comparisons of $\delta^{13} \mathrm{C}$ in whole otoliths and cores from any of the regions investigated (paired $t$-test, $\mathrm{p}>0.05$ ). However, otolith core $\delta^{18} \mathrm{O}$ was higher than whole otolith $\delta^{18} \mathrm{O}$ for YOY red drum in the central and northern regions, being most pronounced in the north $(\mathrm{p}<0.05)$. Otolith core $\delta^{18} \mathrm{O}$ values for subadult and adult red drum were adjusted (NC, SC: $\delta^{18} \mathrm{O}$ $=1.1 ; \mathrm{N}: \delta^{18} \mathrm{O}=1.7$ ) using the mean difference between whole otolith and core from paired comparisons to properly adjust the unknown sample prior to mixed-stock analysis.

\section{RESULTS}

North to south gradients in otolith $\delta^{13} \mathrm{C}$ and $\delta^{18} \mathrm{O}$ of YOY red drum were observed among bays and estuaries sampled, and 4 distinct regional groups were identified using natural variability in otolith isotopic composition (Fig. 4): North (N), Sabine Lake and East Galveston Bay; North-Central (NC), Christmas Bay and Matagorda Bay; South-Central (SC), Aransas Bay and Redfish Bay; and South (S), Laguna Madre (Table 1). Otolith $\delta^{13} \mathrm{C}$ and $\delta^{18} \mathrm{O}$ of YOY red drum varied significantly among the 4 regions (ANOVA, $\mathrm{p}<$ 0.01 ), and univariate contrasts indicated that a region effect was present for both $\delta^{13} \mathrm{C}$ and $\delta^{18} \mathrm{O}$ in 2001, 2002 and 2003 when year classes were analyzed separately (ANOVA, $\mathrm{p}<0.01$ ). Otolith $\delta^{13} \mathrm{C}$ values increased along a north to south gradient, with values over $5.0 \%$ higher (enriched in ${ }^{13} \mathrm{C}$ ) in the $\mathrm{S}$ than the $\mathrm{N}$ region. Mean otolith $\delta^{13} \mathrm{C}$ values (all years pooled) by region

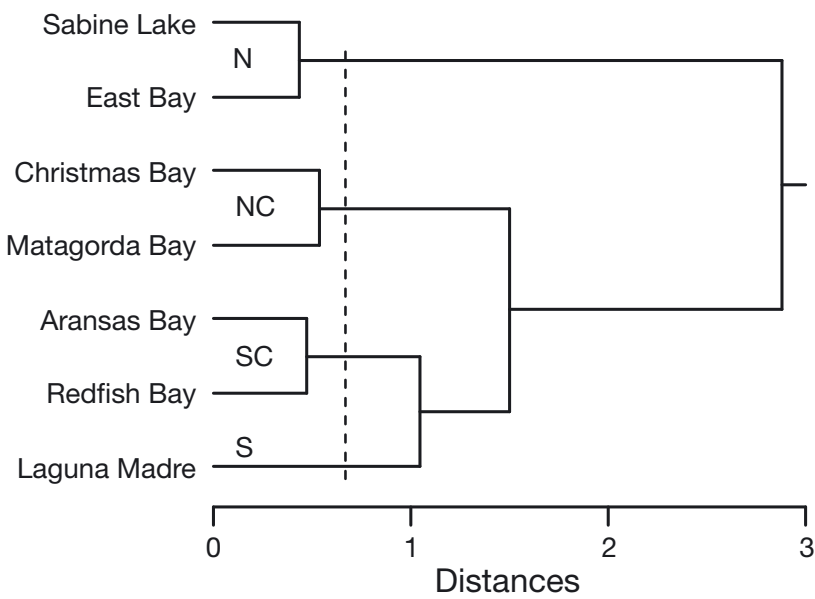

Fig. 4. Sciaenops ocellatus. Tree from hierarchical cluster analysis based on otolith $\delta^{13} \mathrm{C}$ and $\delta^{18} \mathrm{O}$ of young-of-the-year red drum collected from different regions in the northern Gulf of Mexico (year classes pooled). Results based on average linkage and normalized Euclidean distance. Four regional groupings were identified: North $(\mathrm{N})$, North-Central (NC), South-Central (SC) and South (S) 
were: $\mathrm{N}=-5.9 \pm 1.9 \%$, $\mathrm{NC}=-3.3 \pm 1.7 \%$, $\mathrm{SC}=-2.3 \pm$ $1.5 \%$ and $\mathrm{S}=-0.6 \pm 1.9 \%$. Similarly, a significant north to south trend was observed for otolith $\delta^{18} \mathrm{O}$ and values were nearly $3.0 \%$ higher (enriched in ${ }^{18} \mathrm{O}$ ) in the S relative to the $\mathrm{N}$ region. Mean otolith $\delta^{18} \mathrm{O}$ values (all years pooled) by region were: $\mathrm{N}=-3.2 \pm 1.2 \%$, $\mathrm{NC}=$ $-1.8 \pm 0.5 \%$, $\mathrm{SC}=-1.0 \pm 0.4 \%$ and $\mathrm{S}=-0.5 \pm 0.8 \%$.

Otolith $\delta^{13} \mathrm{C}$ and $\delta^{18} \mathrm{O}$ of YOY red drum varied significantly among years within regions (ANOVA, $\mathrm{p}<0.01$; Fig. 5, Table 2), suggesting that water $\delta^{13} \mathrm{C}$ and $\delta^{18} \mathrm{O}$ values within each region varied from year to year. Significant interannual variation in otolith $\delta^{13} \mathrm{C}$ was detected in paired comparisons of YOY baseline samples in all 4 regions (Tukey's HSD, p < 0.05), while a significant difference in otolith $\delta^{18} \mathrm{O}$ was observed between years in $3(\mathrm{~N}, \mathrm{SC}$ and $\mathrm{S})$ of the 4 regions (Tukey's HSD, p < 0.05).
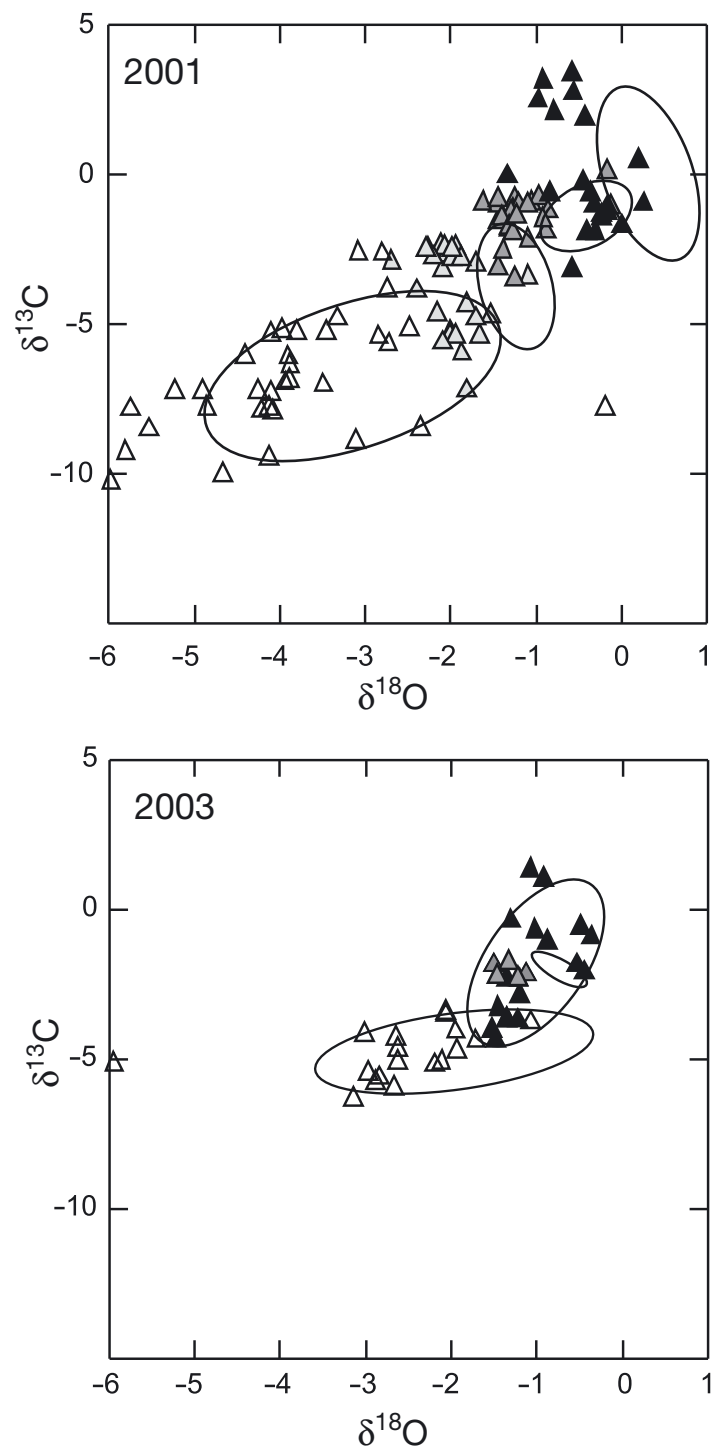

Cross-validated classification success from QDFA to the 4 regions was high for each year class of YOY red drum examined. Classification success was higher for YOY red drum collected in 2001 (92\%) than either $2002(82 \%)$ or 2003 (90\%). Classification success for QDFA models based entirely on otolith $\delta^{18} \mathrm{O}$ was higher (range across years $=76$ to $88 \%$ ) than models including only otolith $\delta^{13} \mathrm{C}$ as a predictor variable (range across years $=57$ to $76 \%$ ), indicating that individually the resolving power of otolith $\delta^{18} \mathrm{O}$ for discriminating regions was greater. However, classification success was highest for models including both $\delta^{13} \mathrm{C}$ and $\delta^{18} \mathrm{O}$, indicating that both markers were useful for discriminating YOY red drum to regional nurseries. Although baseline values varied across years, overall cross-validated classification success to the 4 regions remained relatively high $(77 \%)$ when the 3 year

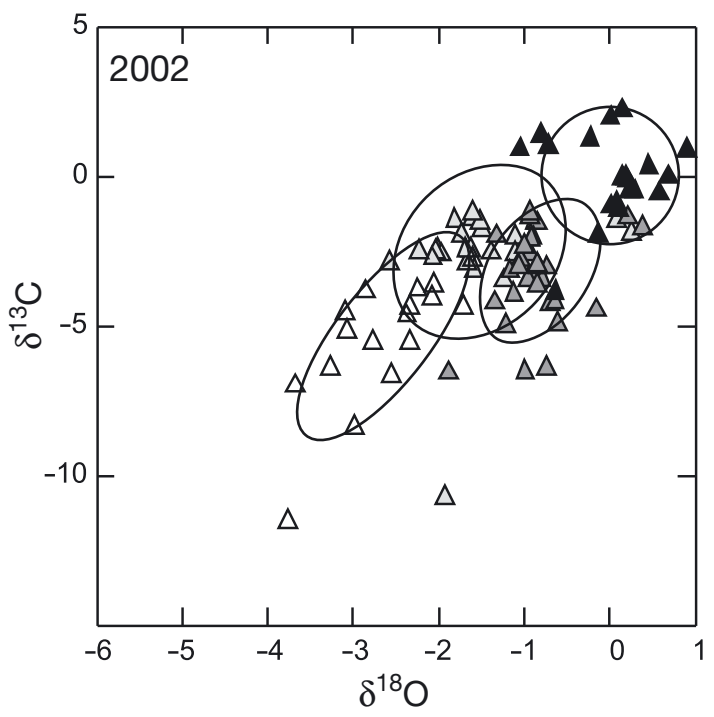

Fig. 5. Sciaenops ocellatus. Otolith $\delta^{13} \mathrm{C}$ and $\delta^{18} \mathrm{O}$ for 3 year classes (2001, 2002 and 2003) of youngof-the-year red drum collected from 4 regions in the northern Gulf of Mexico: North (N), NorthCentral (NC), South-Central (SC) and South (S). Confidence ellipses (1 SD) are shown for each region 
Table 2. Sciaenops ocellatus. Mean \pm SD otolith $\delta^{13} \mathrm{C}$ and $\delta^{18} \mathrm{O}$ of young-of-the-year red drum by region (North [N], NorthCentral [NC], South-Central [SC] and South [S]) and year (2001, 2002 and 2003). nd: no data

\begin{tabular}{|lccc|}
\hline Region & \multicolumn{3}{c|}{ Year } \\
& 2001 & 2002 & 2003 \\
\hline $\boldsymbol{\delta}^{\mathbf{1 3}} \mathbf{C}$ & & & \\
$\mathrm{N}$ & $-6.7 \pm 1.9$ & $-5.4 \pm 2.1$ & $-4.8 \pm 0.8$ \\
$\mathrm{NC}$ & $-3.8 \pm 1.4$ & $-2.5 \pm 1.8$ & nd \\
$\mathrm{SC}$ & $-1.4 \pm 0.8$ & $-3.1 \pm 1.5$ & $-2.0 \pm 0.2$ \\
$\mathrm{~S}$ & $0.0 \pm 1.9$ & $0.0 \pm 1.4$ & $-1.9 \pm 1.7$ \\
$\boldsymbol{\delta}^{\mathbf{1 8}} \mathbf{O}$ & & & \\
$\mathrm{N}$ & $-3.9 \pm 1.1$ & $-2.6 \pm 0.6$ & $-2.6 \pm 1.0$ \\
$\mathrm{NC}$ & $-2.0 \pm 0.3$ & $-1.5 \pm 0.6$ & $\mathrm{nd}$ \\
$\mathrm{SC}$ & $-1.2 \pm 0.4$ & $-0.8 \pm 0.5$ & $-1.3 \pm 0.1$ \\
$\mathrm{~S}$ & $-0.4 \pm 0.4$ & $-0.1 \pm 0.5$ & $-1.1 \pm 0.8$ \\
\hline
\end{tabular}

classes were pooled, indicating the baseline was relatively robust and likely suitable for predicting the origin of sub-adult and adult red drum whose first year of life was within a few years of the baseline period.

Otolith core $\delta^{13} \mathrm{C}$ and $\delta^{18} \mathrm{O}$ values of age-2+ red drum collected in 2003 from all 4 regions were matched to the 2001 baseline to determine their nursery origin (Fig. 6). Similar to YOY red drum, mean otolith core $\delta^{13} \mathrm{C}$ of age-2+ red drum varied by region with values becoming higher with decreasing latitude: $\mathrm{N}=-4.3 \pm$ $1.8 \%$, NC $=-2.9 \pm 1.1 \%, \mathrm{SC}=-1.7 \pm 1.2 \%$ and $\mathrm{S}=$ $-1.1 \pm 1.5 \%$. Otolith core $\delta^{18} \mathrm{O}$ values for age-2+ red drum were also highest and lowest in the $\mathrm{S}$ and $\mathrm{N}$ regions, respectively: $\mathrm{N}=-3.0 \pm 1.0 \%, \mathrm{NC}=-0.9 \pm$ $1.0 \%$, SC $=-0.7 \pm 0.9 \%$ and $\mathrm{S}=-0.1 \pm 0.7 \%$. The general trend of increasing otolith core $\delta^{13} \mathrm{C}$ and $\delta^{18} \mathrm{O}$ values from northern to southern regions was also observed for older red drum with YOY periods outside our baseline (age- $3+$ or older, $\mathrm{n}=59$ ).

Direct maximum likelihood estimates of age-2+ red drum collected in 2003 and matched to the 2001 baseline $(n=89)$ indicated that the majority of sub-adult and adult red drum sampled in the SC and S regions were produced from the same areas (82 and $91 \%$, respectively), with limited exchange between these regions (Table 3). In the $\mathrm{N}$ and $\mathrm{NC}$ regions, percentages were lower of age-class matched red drum present in the same region occupied during the YOY period (54 and $47 \%$, respectively), and most of the remaining age-2+ red drum in both regions were produced from the next contiguous nursery to the south. In fact, the remaining age-2+ red drum in the $\mathrm{N}$ region were almost entirely of $\mathrm{NC}$ origin $(42 \%)$, while in the

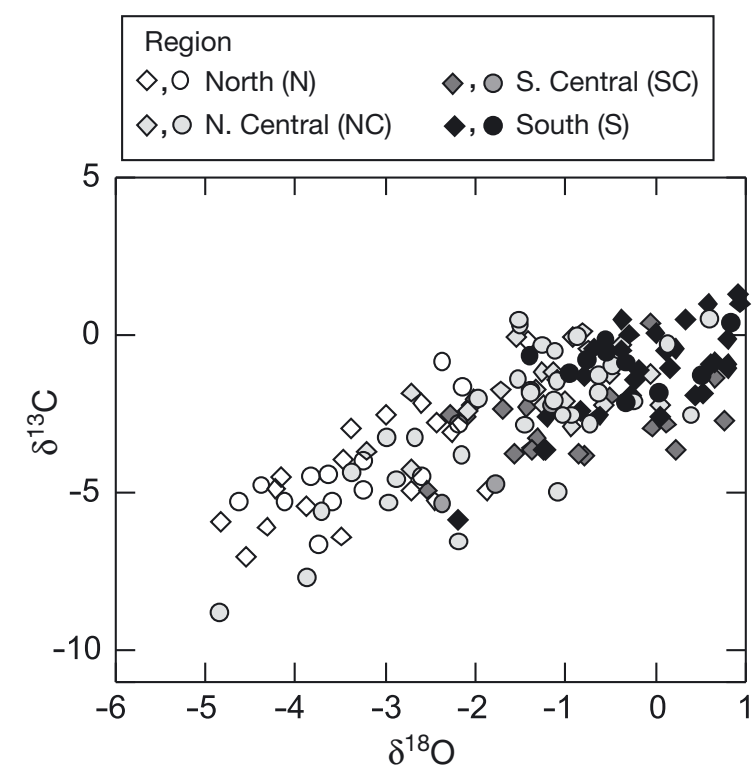

Fig. 6. Sciaenops ocellatus. Otolith core $\delta^{13} \mathrm{C}$ and $\delta^{18} \mathrm{O}$ from sub-adult and adult red drum collected from 4 regions in 2003 in the northern Gulf of Mexico: North $(\mathrm{N})$, North-Central (NC), South-Central (SC) and South (S). Otolith cores that fell outside the $95 \%$ confidence ellipse of the baseline $(n=4)$ were omitted from the plot. Age-2+ red drum matched to baseline are denoted by diamonds; circles represent individuals that could not be age-class matched

$\mathrm{NC}$ region the contribution from the $\mathrm{SC}$ region was $35 \%$. Mixed-stock analysis was also performed on a group of age-3+ or older red drum $(n=59)$, with YOY periods outside the 2001 baseline period. In all 4 regions, the majority of sub-adult and adult red drum

Table 3. Sciaenops ocellatus. Estimates of natal origin (percent composition, $\pm \mathrm{SD}$ ) of sub-adult and adult red drum collected from 4 regions (North [N], North-Central [NC], South-Central [SC] and South [S]) in the northern Gulf of Mexico. Otolith core $\delta^{13} \mathrm{C}$ and $\delta^{18} \mathrm{O}$ of young-of-the-year (YOY) red drum from 2001 were used as the baseline to estimate the origin of age-2+ red drum with YOY periods that matched 2001 baseline $(\mathrm{N}=89)$ and age-3+ or older red drum with YOY period outside baseline $(\mathrm{N}=59) . N$ : sample size. Percent values in bold denote sub-adult or adult red drum that originated from the same nursery as collection location

\begin{tabular}{|c|c|c|c|c|c|}
\hline \multirow{2}{*}{$\begin{array}{l}\text { Region } \\
\text { collected }\end{array}$} & \multirow[t]{2}{*}{$N$} & \multicolumn{4}{|c|}{ Predicted origin } \\
\hline & & $\mathrm{N}$ & $\mathrm{NC}$ & $\mathrm{SC}$ & $\mathrm{S}$ \\
\hline \multicolumn{6}{|c|}{ Age-class matched (age-2+) } \\
\hline $\mathrm{N}$ & 17 & $54.0 \pm 15.9$ & $42.2 \pm 15.5$ & $3.8 \pm 5.4$ & $0.0 \pm 0.0$ \\
\hline $\mathrm{NC}$ & 21 & $0.0 \pm 0.0$ & $47.1 \pm 21.2$ & $34.9 \pm 30.4$ & $18.0 \pm 15.4$ \\
\hline $\mathrm{SC}$ & 20 & $0.0 \pm 0.0$ & $14.7 \pm 11.0$ & $82.0 \pm 13.0$ & $3.1 \pm 8.0$ \\
\hline $\mathrm{S}$ & 31 & $0.0 \pm 0.0$ & $4.6 \pm 4.7$ & $4.4 \pm 8.6$ & $91.0 \pm 8.8$ \\
\hline \multicolumn{6}{|c|}{ Outside baseline (age-3+ or older) } \\
\hline $\mathrm{N}$ & 14 & $58.9 \pm 15.6$ & $31.2 \pm 19.5$ & $9.9 \pm 11.6$ & $0.0 \pm 0.0$ \\
\hline NC & 3 & $0.0 \pm 0.0$ & $77.3 \pm 25.2$ & $22.7 \pm 25.2$ & $0.0 \pm 0.0$ \\
\hline $\mathrm{SC}$ & 32 & $11.5 \pm 6.5$ & $21.0 \pm 9.0$ & $50.7 \pm 16.9$ & $16.9 \pm 13.9$ \\
\hline $\mathrm{S}$ & 10 & $0.0 \pm 0.0$ & $0.0 \pm 0.0$ & $1.5 \pm 10.5$ & $98.6 \pm 10.5$ \\
\hline
\end{tabular}


were produced from the same region (range: 51 to $99 \%$ ) and, similar to the age-class matched individuals, the contribution of other nurseries was lowest in the $\mathrm{S}$ region (Table 3 ).

\section{DISCUSSION}

Spatial variation in otolith $\delta^{13} \mathrm{C}$ was evident for YOY red drum with values increasing from north to south. Otolith $\delta^{13} \mathrm{C}$ was highest for red drum collected in hypersaline waters of the $\mathrm{S}$ region (Laguna Madre), and positive relationships between salinity and measures of otolith $\delta^{13} \mathrm{C}$ have been reported in other estuaries (Harrod et al. 2005, Kerr et al. 2007), supporting the observed pattern in our baseline values for YOY red drum. The relationship between salinity and otolith $\delta^{13} \mathrm{C}$ observed along the Texas coast is likely regulated by freshwater inflow (precipitation), with more southerly locations (higher salinity) receiving less freshwater inflow, and thus less terrestrial carbon which lowers the $\delta^{13} \mathrm{C}$ in the dissolved inorganic carbon (DIC) pool (Michener and Schell 1994). Differences in diet have also been shown to affect otolith $\delta^{13} \mathrm{C}$ (Thorrold et al. 1997, Høie et al. 2004), and thus diet may be partly responsible for observed differences. In Texas, the areal coverage of seagrass increases from north to south, and its role as a primary source of organic matter is substantially higher in the south (Adair et al. 1994). Carbon isotope values in sediments and tissues of consumers in areas with significant seagrass coverage (e.g. Laguna Madre) reflect the inputs of these ${ }^{13} \mathrm{C}$-enriched producers $\left(\delta^{13} \mathrm{C}=-10\right.$ to $-12 \%$ ) relative to the north, where a large fraction of organic matter is derived from phytoplankton $\left(\delta^{13} \mathrm{C}=\right.$ -19 to $-21 \%$ ) or other sources of primary production such as salt marsh or benthic algae (Benedict et al. 1980, Herzka et al. 2001, Fry 2006, Fry et al. 2008). Therefore, it is possible that higher $\delta^{13} \mathrm{C}$ values in the otoliths of YOY red drum from the south (seagrass dominated) compared to the north (seagrass limited) are related to the isotopic values of the dominant producers, albeit the direct effect of seagrass is likely minor because seagrass carbon is relatively refractory and most of the otolith carbon is expected to come from DIC in the water (Campana 1999). Although changes in $\delta^{13} \mathrm{C}$ of the DIC pool related to freshwater inflow and, to a lesser extent, in $\delta^{13} \mathrm{C}$ of the diet appear responsible for the observed gradient in otolith $\delta^{13} \mathrm{C}$, changes in metabolism due to temperature or feeding related shifts (Thorrold et al. 1997, Høie et al. 2003) may also account for some of the observed variability.

Similar to otolith $\delta^{13} \mathrm{C}$, a north-south gradient was observed for otolith $\delta^{18} \mathrm{O}$ in YOY red drum, with higher values present in the hypersaline waters of the $\mathrm{S}$ region and, to a lesser extent, the $\mathrm{SC}$ region relative to regions of high freshwater inflow in the north (N, NC). The observed pattern of increasing otolith $\delta^{18} \mathrm{O}$ with increasing salinity has been reported in other studies, and results from the combined effects of evaporation (water enriched in ${ }^{18} \mathrm{O}$ ) and freshwater inflow (rainwater depleted in ${ }^{18} \mathrm{O}$ ) (Campana 1999). In previous studies, otolith $\delta^{18} \mathrm{O}$ has been shown to increase by approximately 0.1 to $1.4 \%$ with salinity increasing by a practical salinity of 1 (e.g. Dufour et al. 1998, Bastow et al. 2002). Mean salinity in the $\mathrm{S}$ region of Laguna Madre (practical salinity $\sim 35$ to 40 ) is often 25 higher than sites in the $\mathrm{N}$ region (e.g. Sabine Lake, practical salinity $\sim 10$; Longley et al. 1994), which would translate to a difference in otolith $\delta^{18} \mathrm{O}$ of 2.5 to $4.2 \%$ between the $\mathrm{N}$ and $\mathrm{S}$ regions using the $\delta^{18} \mathrm{O}$-salinity relationships described above. Mean otolith $\delta^{18} \mathrm{O}$ was $2.7 \%$ higher in the $\mathrm{S}$ than $\mathrm{N}$ region for YOY red drum and falls within the predicted range, suggesting that processes influencing salinity may be largely responsible for spatial variation in otolith $\delta^{18} \mathrm{O}$ values. Variability in otolith $\delta^{18} \mathrm{O}$ of YOY red drum also may be linked to temperature-dependent fractionation, but an inverse relationship between otolith $\delta^{18} \mathrm{O}$ and temperature is expected (Høie et al. 2004). For YOY red drum, a positive otolith $\delta^{18} \mathrm{O}$-temperature relationship was observed, with higher values for individuals from the warmer waters of the S region. Similar to the findings of Kerr et al. (2007), it appears that salinity was the dominant factor accounting for observed differences in otolith $\delta^{18} \mathrm{O}$. The influence of temperature was likely negligible in the present study for the simple fact that temperature differences between the $\mathrm{N}$ and $\mathrm{S}$ regions are small (ca. 2 to $3^{\circ} \mathrm{C}$, Simons \& Smith 2009; http://co-ops.nos.noaa.gov) relative to large $(\geq 25)$ salinity differences (Orlando et al. 1991), which again are linked to regional differences in freshwater inflow (higher in the $\mathrm{N}$ region) and evaporation (higher in the $\mathrm{S}$ region).

Temporal variability in otolith $\delta^{13} \mathrm{C}$ and $\delta^{18} \mathrm{O}$ was assessed by examining 3 cohorts of YOY red drum, and differences were detected among years for both stable isotopes. Interannual variability in the chemical composition of otoliths is well documented for trace elements and stable isotopes (Elsdon et al. 2008, Schloesser et al. 2009). Temporal shifts in baseline values often necessitate the matching of sub-adults or adults to juveniles from specific year classes (Gillanders 2005). In the present study, we observed that classification success to the 4 regions investigated was high when maximum likelihood estimates of origin were run separately by year. Moreover, discrimination of YOY red drum from the 4 regions in 2001, which served as the baseline for age-class matching of age$2+$ red drum collected in 2003, was the highest of all 
years examined $(92 \%)$. Classification success declined when all 3 year classes were pooled $(77 \%)$, suggesting that changes in environmental factors known to affect $\delta^{13} \mathrm{C}$ and $\delta^{18} \mathrm{O}$ of water (e.g. rainfall, evaporation and temperature) varied among years. Of the 4 regions examined, interannual variability in otolith $\delta^{13} \mathrm{C}$ and $\delta^{18} \mathrm{O}$ of YOY red drum was most pronounced in the $\mathrm{N}$ region, which is consistent with the greater and more variable input of freshwater here relative to more southerly regions. In fact, the lowest otolith $\delta^{13} \mathrm{C}$ and $\delta^{18} \mathrm{O}$ values in the $\mathrm{N}$ region were observed in 2001 when freshwater inflow out of the main tributary (Sabine) in this region was highest of the 3 years examined (Texas Water Development Board 2007). The size and frequency of pulsed freshwater events in the $\mathrm{N}$ region were markedly higher than all other regions, with annual inflows (Sabine) being an order of magnitude higher than the $\mathrm{S}$ region (Laguna Madre) (ca. 12.0 and $<1.0$ million acre-ft $\left[\sim 14.8\right.$ to $\left.1.2 \times 10^{9} \mathrm{~m}^{3}\right]$, respectively; Texas Water Development Board 2007). This trend in freshwater input is consistent with the high degree of interannual variability observed for otolith $\delta^{13} \mathrm{C}$ and $\delta^{18} \mathrm{O}$ for YOY red drum from this region.

Milled otolith cores of sub-adult and adult red drum were matched to the baseline sample using a mixedstock algorithm, and results clearly showed that a large fraction of age-2+ red drum from each of the 4 regions were produced from nurseries in the same region, suggestive of limited movement. Observed fidelity of subadult and adult red drum to natal sites may be due to localized retention or limited inter-estuary movement, which is common for species in the family Sciaenidae, including red drum (Baker \& Matlock 1993, Murphy et al. 1998, Adams \& Tremain 2000). Mark-recapture studies on red drum in the Gulf of Mexico and along the eastern seaboard of the US have shown that the majority of individuals originated from nurseries within the same estuary or region as the capture location (Osborn et al. 1982, Overstreet 1983, Nicholson \& Jordan 1994). Moreover, Tremain et al. (2004) observed high site fidelity of red drum from a no-take zone in Florida, with over $95 \%$ of the recaptures occurring at the tagging location within the reserve. Genetic divergence of red drum across estuaries in the northern Gulf of Mexico has also been detected, but gene flow and stock mixing among regional estuaries is still assumed to be limited (Gold et al. 2001, Gold \& Turner 2002). As a result, inter-estuary movements or straying behavior may be less common or on a smaller scale, particularly for young adults ( age-2+) that have only recently moved out of estuarine nursery areas.

An alternative explanation for the apparent fidelity of sub-adult and adult red drum to natal sites may be due to homing behavior. Evidence for natal homing is well established for anadromous species, including certain clupeids (Walther et al. 2008), moronids (Waldman et al. 1996, Wingate \& Secor 2007) and salmonids (Quinn 1993, Lohmann et al. 2008); nevertheless, few documented cases of homing exist for sciaenids and other estuarine-dependent taxa. Using otolith chemistry, Thorrold et al. (2001) reported natal homing rates of weakfish Cynoscion regalis to estuaries along the eastern seaboard to be from 60 to $81 \%$, with the majority of mixing limited to adjacent estuaries. Similarly, Patterson et al. (2004) examined a small number of adult red drum $(\mathrm{n}=20)$ from a single bay in Florida and estimated that $75 \%$ originated from nurseries in the same bay. In the present study, estimates of potential homing to specific estuaries on the lower coast of Texas ( $\mathrm{S}, \mathrm{SC}$ regions) were relatively high and within or above the aforementioned range. More mixing occurred in the northern regions, with the majority of the migrants in each region originating from the adjacent region to the south, suggesting that most of the age-2+ or older red drum examined stayed within or in close proximity $(<100 \mathrm{~km})$ to their nursery sites. Alternatively, lower survival of migrants originating from outside nurseries may also explain the lower contribution rates and/or mixing of individuals from other regions. Although the dispersal potential of adult red drum is assumed to be high (Overstreet 1983), additional information on movement away from estuarine nurseries is needed to confirm that homing, rather than retention, was the primary behavior responsible for red drum being in tidal passes or coastal environments nearest to their putative nursery. The combined effects of localized retention and natal homing explain findings from tagging, genetics and otolith chemistry, but the degree to which each behavior is responsible for observed patterns remains unresolved. Moreover, red drum is long lived ( $>25 \mathrm{yr}$; Beckman et al. 1988, Murphy \& Taylor 1990, Murphy \& Crabtree 2001); therefore, our assessment was limited to the early adult phase. Homing behavior of marine fishes often varies as a function of age (e.g. Rooker et al. 2008a), suggesting that a wide range of adult age classes may be required to accurately depict the dispersive behaviors of red drum.

The relative value of presumed nurseries is commonly based on indirect measures of recruitment potential (Houde 2002), although such measures do not provide a means of determining actual contribution rates nor do they quantify levels of connectivity among estuarine ecosystems. Results presented here clearly demonstrate that otolith $\delta^{13} \mathrm{C}$ and $\delta^{18} \mathrm{O}$ represent viable markers of nursery origin that can be used to assess contribution rates of different nurseries to adult populations of red drum and possibly other estuarinedependent fishes. Our findings suggest that mixing occurs among regional estuaries in the Gulf of Mexico, 
but the majority of sub-adult and adult red drum appear to either remain in close proximity to their estuarine nurseries or return to natal areas to spawn following a dispersive phase. Either way, fishery yields of red drum appear directly linked to local production, with supplementary contributions from adjacent estuaries. Local-scale effects (e.g. pollution, fishing pressure and freshwater inflow) will therefore influence population dynamics of red drum within a specific region, signifying that spatially explicit management may be needed at smaller scales (i.e. bays or estuaries) to facilitate desired levels of production throughout the geographic range of this species.

Acknowledgements. We thank A. Davis, C. Pratt, R. Schloesser, D. Wells and M. Zapp for their assistance in the field or lab. Funding for this study was provided by Texas Sea Grant (NOAA award \# NA06OAR4170076.

\section{LITERATURE CITED}

Able KW (2005) A re-examination of fish estuarine dependence: evidence for connectivity between estuarine and ocean habitats. Estuar Coast Shelf Sci 64:5-17

Able KW, Balletto JH, Hagan SM, Jivoff PR, Strait K (2007) Linkages between salt marshes and other nekton habitats in Delaware Bay, USA. Rev Fish Sci 15:1-61

Adair SE, Moore JL, Onuf CP (1994) Distribution and status of submerged vegetation in estuaries of the upper Texas coast. Wetlands 14:110-121

Adams DH, Tremain DM (2000) Association of large juvenile red drum, Sciaenops ocellatus, with an estuarine creek on the Atlantic coast of Florida. Environ Biol Fishes 58:183-194

Baker WB, Matlock GC (1993) Movement of spotted seatrout tagged in Trinity Bay, Texas. Northeast Gulf Sci 13:29-34

Bastow TP, Jenkins G, Edmonds JS (2002) Elevated salinity and isotopic composition of fish otolith carbonate: stock delineation of pink snapper, Pagrus auratus, in Shark Bay, Western Australia. Mar Biol 141:801-806

Beck MW, Heck KL, Able KW, Childers DL and others (2001) The identification, conservation, and management of estuarine and marine nurseries for fish and invertebrates. Bioscience 51:633-641

Beckman DW, Wilson CA, Stanley AL (1988) Age and growth of red drum, Sciaenops ocellatus, from offshore waters of the Gulf of Mexico. Fish Bull 87:17-28

Benedict CR, William WWL, Wong JHH (1980) Fractionation of the stable isotopes of inorganic carbon by seagrasses. Plant Physiol 65:512-517

Bottom DL, Jones KK, Cornwell JJ, Gray A, Simenstad CA (2005) Patterns of Chinook salmon migration and residency in the Salmon River estuary (Oregon). Estuar Coast Shelf Sci 64:79-93

Bradbury IR, Campana SE, Bentzen P (2008) Low genetic connectivity in an estuarine fish with pelagic larvae. Can J Fish Aquat Sci 65:147-158

Brown CA, Holt SA, Jackson GA, Brooks DA, Holt GJ (2004) Simulating larval supply to estuarine nursery areas: How important are physical processes to the supply of larvae to the Aransas Pass Inlet? Fish Oceanogr 13:181-196

Campana SE (1999) Chemistry and composition of fish otoliths: pathways, mechanisms and applications. Mar Ecol Prog Ser 188:263-297
Chittaro PM, Finley RJ, Levin PS (2009) Spatial and temporal patterns in the contribution of fish from their nursery habitats. Oecologia 160:49-61

Dufour V, Pierre C, Rancher J (1998) Stable isotopes in fish otoliths discriminate between lagoonal and oceanic residents of Taiaro Atoll (Tuamotu Archipelago, French Polynesia). Coral Reefs 17:23-28

Elsdon TS, Wells BK, Campana SE, Gillanders BM and others (2008) Otolith chemistry to describe movements and lifehistory parameters of fishes: hypotheses, assumptions, limitations and inferences. Oceanogr Mar Biol Annu Rev 46:297-330

Fodrie FJ, Herzka SZ (2008) Tracking juvenile fish movement and nursery contribution within arid coastal embayments via otolith microchemistry. Mar Ecol Prog Ser 361:253-265

Fry B (2006) Stable isotope ecology. Springer, New York, NY

- Fry B, Cieri M, Hughes J, Tobias C, Deegan LA, Peterson B (2008) Stable isotope monitoring of benthic-planktonic coupling using salt marsh fish. Mar Ecol Prog Ser 369: 193-204

> Gillanders BM (2002) Temporal and spatial variability in elemental composition of otoliths: implications for determining stock identity and connectivity of populations. Can J Fish Aquat Sci 59:669-679

Gillanders BM (2005) Using elemental chemistry of fish otoliths to determine connectivity between estuarine and coastal habitats. Estuar Coast Shelf Sci 64:47-57

Gold JR, Turner TF (2002) Population structure of red drum (Sciaenops ocellatus) in the northern Gulf of Mexico, as inferred from variation in nuclear-encoded microsatellites. Mar Biol 140:249-265

Gold JR, Burridge CP, Turner TF (2001) A modified steppingstone model of population structure of red drum, Sciaenops ocellatus, from the northern Gulf of Mexico. Genetica 111:305-317

Hamer PA, Jenkins GP, Gillanders BM (2005) Chemical tags in the otoliths indicate the importance of local and distant settlement areas to populations of a temperate sparid, Pagrus auratus. Can J Fish Aquat Sci 62:623-630

Harrod C, Grey J, McCarthy TK, Morrissey M (2005) Stable isotope analyses provide new insights into ecological plasticity in a mixohaline population of European eel. Oecologia 144:673-683

Herzka SZ, Holt SA, Holt GJ (2001) Documenting the settlement history of individual fish larvae using stable isotope ratios: model development and validation. J Exp Mar Biol Ecol 265:49-74

> Høie H, Folkvord A, Otterlei E (2003) Effect of somatic and otolith growth on stable isotopic composition of early juvenile cod (Gadus morhua L) otoliths. J Exp Mar Biol Ecol 289:41-58

Høie H, Otterlei E, Folkvord A (2004) Temperaturedependent fractionation of stable oxygen isotopes in otoliths of juvenile cod (Gadus morhua L.). ICES J Mar Sci 61:243-251

Houde ED (2002) Mortality. In: Fuiman LA, Werner RG (eds) Fishery science: the unique contributions of early life stages. Blackwell Science, Oxford, p 64-87

Kerr LA, Secor DH, Kraus RT (2007) Stable isotope $\left(\delta^{13} \mathrm{C}\right.$ and $\delta^{18} \mathrm{O}$ ) and $\mathrm{Sr} / \mathrm{Ca}$ composition of otoliths as proxies for environmental salinity experienced by an estuarine fish. Mar Ecol Prog Ser 349:245-253

Levin PS, Stunz GW (2005) Habitat triage for exploited fishes: Can we identify essential 'Essential Fish Habitat?' Estuar Coast Shelf Sci 64:70-78

> Lohmann KJ, Putman NF, Lohmann CMF (2008) Geomagnetic imprinting: a unifying hypothesis of long-distance 
natal homing in salmon and sea turtles. Proc Natl Acad Sci USA 105:19096-19101

Longley WL, Powell GL, Green AW (1994) Freshwater inflows to Texas bays and estuaries: ecological relationships and methods for determination of needs. Texas Water Development Board \& Texas Parks and Wildlife Department, Austin, TX

Michener RH, Schell DM (1994) Stable isotope rations as tracers in marine aquatic food webs. In Lajtha K, Michener $\mathrm{RH}$ (eds) Stable isotopes in ecology and environmental science. Blackwell Scientific, Oxford, p 138-157

Millar RB (1990) Comparison of methods for estimating mixed stock fishery composition. Can J Fish Aquat Sci 47: 2235-2241

Murphy MD, Crabtree RE (2001) Changes in the age structure of nearshore adult red drum off west-central Florida related to recruitment and fishing mortality. N Am J Fish Manag 21:671-678

Murphy MD, Taylor RG (1990) Reproduction, growth, and mortality of red drum (Sciaenops ocellatus) in Florida waters. Fish Bull 88:531-542

Murphy MD, Adams DH, Tremain DM, Winner BW (1998) Direct validation of ages determined for adult black drum, Pogonias cromis, in east central Florida, with notes on black drum migration. Fish Bull 88:382-387

Nicholson N, Jordan SR (1994) Biotelemetry study of red drum in Georgia, November 1989-June 1993. Georgia Department of Natural Resources, Coastal Resources Division, Brunswick, GA

Orlando S Jr, Rozas L, Ward G, Klein CJ (1991) Analysis of salinity structure and stability for Texas estuaries. NOAA, Strategic Assessment Branch, NOS, Rockville, MD

Osborn HR, Matlock GC, Green AW (1982) Red drum (Sciaenops ocellatus) in Texas bays. Contrib Mar Sci 25: 85-97

Overstreet RM (1983) Aspects of the biology of red drum, Sciaenops ocellatus, in Mississippi. Gulf Res Rep (Suppl 1): $45-68$

Patterson HM, McBride RS, Julien N (2004) Population structure of red drum (Sciaenops ocellatus) as determined by otolith chemistry. Mar Biol 144:855-862

Quinn TP (1993) A review of homing and straying of wild and hatchery-produced salmon. Fish Res 18:29-44

Rooker JR, Kraus R, Secor DH (2004) Dispersive behaviors of

Editorial responsibility: Ivan Nagelkerken,

Nijmegen, Netherlands black drum and red drum: Is otolith $\mathrm{Sr}$ :Ca a reliable indicator of salinity history? Estuaries 27:334-341

Rooker JR, Secor DH, De Metrio G, Kaufman JA, Belmonte Rios A, Ticina A (2008a) Evidence of trans-Atlantic mixing and natal homing of bluefin tuna from stable isotopes in otoliths. Mar Ecol Prog Ser 368:231-239

> Rooker JR, Secor DH, De Metrio G, Schloesser R, Block BA, Neilson JD (2008b) Natal homing and connectivity in Atlantic bluefin tuna populations. Science 322:742-744

Schloesser RW (2009) Natal origin of Atlantic bluefin tuna (Thunnus thynnus) from the Gulf of St. Lawrence using $\delta^{13} \mathrm{C}$ and $\delta^{18} \mathrm{O}$ in otoliths. MSc thesis, Texas A\&M University, College Station, TX

Schloesser RW, Rooker JR, Louchuoarn P, Neilson JD, Secor $\mathrm{DH}$ (2009) Interdecadal variation in seawater $\delta^{13} \mathrm{C}$ and $\delta^{18} \mathrm{O}$ recorded in fish otoliths. Limnol Oceanogr 54:1665-1668

Secor DH, Rooker JR (2005) Connectivity in the life histories of fishes that use estuaries. Estuar Coast Shelf Sci 64:1-3

Simons JD, Smith CR (2009) Texas National Coastal Assessment (2000-2004): challenges, solutions, lessons learned and future directions. Environ Monit Assess 150:167-179

Texas Water Development Board (2007) State water plan for Texas, Vol I. Highlights of the 2007 state water plan. Document no. GP-8-1. Texas Water Development Board, Austin, TX

Thorrold SR, Campana SE, Jones CM, Swart PK (1997) Factors determining $\delta^{13} \mathrm{C}$ and $\delta^{18} \mathrm{O}$ fractionation in aragonitic otoliths of marine fish. Geochim Cosmochim Acta 61: $2909-2919$

Thorrold SR, Latkoczy C, Swart PK (2001) Natal homing in a marine fish metapopulation. Science 291:297-299

Tremain DM, Harnden CW, Adams DH (2004) Multidirectional movements of sportfish species between an estuarine no-take zone and surrounding waters of the Indian River Lagoon, Florida. Fish Bull 102:533-544

> Waldman JR, Nolan K, Hart J, Wirgin LL (1996) Genetic differentiation of three key anadromous fish populations of the Hudson River. Estuaries 19:759-768

> Walther BD, Thorrold SR, Olney JE (2008) Geochemical signatures in otoliths record natal origins of American shad. Trans Am Fish Soc 137:57-69

Wingate RL, Secor DH (2007) Intercept telemetry of the Hudson River striped bass resident contingent: migration and homing patterns. Trans Am Fish Soc 136:95-104

Submitted: June 16, 2009; Accepted: February 26, 2010 Proofs received from author(s): April 27, 2010 